J. Clin. Chem. Clin. Biochem.

Vol. 24, 1986, pp. $521-528$

(C) 1986 Walter de Gruyter \& Co.

Berlin - New York

\title{
Fibronectin is Synthesized as an Acute Phase Reactant in Rat Hepatocytes
}

\author{
By K.-H. Pick-Kober, Doris Münker and A. M. Gressner \\ Department of Clinical Chemistry and Central Laboratory, Philipps-University Marburg, FRG
}

(Received December 19, 1985/March 17, 1986)

\begin{abstract}
Summary: Elevated concentrations of fibronectin were found in plasma of rats under different acute phase conditions. Untreated animals showed a plasma fibronectin concentration of $150 \pm 50 \mathrm{mg} / \mathrm{l}$, which increased to $412 \pm 59 \mathrm{mg} / \mathrm{l} 24 \mathrm{~h}$ after subcutaneous injection of turpentine. The time course of the changes in plasma fibronectin concentration showed a peak at $24 \mathrm{~h}$ and a decline to normal concentrations $72 \mathrm{~h}$ after turpentine treatment. Additional stimulation by dexamethasone resulted in plasma fibronectin concentrations of $661 \pm$ $49 \mathrm{mg} / \mathrm{l}$. No or only slight elevations of fibronectin concentrations were observed after treatment with adrenaline, thyroxine and triiodothyronine as compared with saline-injected animals. The common identity of plasma fibronectin in controls, turpentine and turpentine-dexamethasone-treated animals was shown by slab gel electrophoresis under nonreducing conditions, followed by western blot and immunofluorescence staining. One dimensional immunoelectrophoresis performed with polyclonal antibodies to human fibronectin cross-reacting with rat fibronectin (shown by Ouchterlony gel diffusion) revealed indentical precipitation lines for the plasma of control and acute phase animals. Hepatocytes of turpentine-pretreated rats show a threefold increase of $\left[{ }^{14} \mathrm{C}\right]$ valine incorporation into total protein and a fourfold increase of immunoreactive radioactively labeled fibronectin in the culture medium, compared with control hepatocyte cultures. These results point to the role of hepatocytes in the synthesis of plasma fibronectin, which behaves in rats as an acute phase reactant.
\end{abstract}

\section{Die Synthese von Fibronektin als Akute-Phase-Reaktant durch Rattenhepatocyten}

Zusammenfassung: Im Plasma von Ratten werden unter verschiedenen Akute-Phase-Bedingungen im Vergleich zu unbehandelten Kontrolltieren erhöhte Fibronektinkonzentrationen gemessen. 24 Stunden nach subkutaner Terpentininjektion liegt die Fibronektinkonzentration im Plasma bei $412 \pm 59 \mathrm{mg} / \mathrm{l}$ (Kontrolltiere $150 \pm 50 \mathrm{mg} / \mathrm{l})$. Nach einem schnellen Anstieg innerhalb von 6 Stunden erreicht die Fibronektinkonzentration nàch 24 Stunden ein Maximum und fällt dann kontinuierlich ab, um nach 72 Stunden Kontrollwerte zu erreichen. Zusätzliche hormonelle Stimulation nach Terpentingabe durch Dexamethason führt zu Plasmafibronektinkonzentrationen von $661 \pm .49 \mathrm{mg} / \mathrm{l}$. Weitere Hormone wie Adrenalin, Thyroxin und Triiodthyronin èrgeben keine bžw. nur eine geringe Erhöhung der Fibronektinkonzentration im Plasma.

In der Flachbett-Polyacrylamid-Gelelektrophorese wurde durch Immunfluoreszenzanfärbung ein einheitliches, mit anti-Humanfibronektin-Antiserum reagierendes Protein im Plasma von Kontrollratten und Terpentin- bzw. Terpentin + Dexamethason-behandelten Tieren nachgewiesen. Ebenso zeigt die eindimensionale Immunelektrophorese mit polyklonalen, mit Rattenfibronektin kreuzreagierenden Antikörpern gegen Humanfibronektin (nachgewiesen in der Geldiffusion nach Ouchterlony) identische Präzipitate im Plasma aus Kontroll- und Akute-Phase-Tieren. Hepatocyten aus terpentinvorbehandelten Tieren zeigten eine erhöhte Proteinsynthese mit einem dreifach gesteigerten Einbau von $\left[{ }^{14} \mathrm{C}\right]$ Valin in Gesamtprotein und einem vierfachen Anstieg des immunreaktiven, radioaktiv markierten Fibronektins im Kulturmedium im Vergleich zu Hepatocyten aus. Kontrolltieren. Die Ergebnisse weisen auf die Bedeutung der Hepatocyten für die Synthese von Plasmafibronektin unter Akute-Phase-Bedingungen hin. 


\section{Introduction}

Fibronectin is a dimeric glycoprotein with a relative molecular mass of $M_{\mathrm{r}}=440000$, which is present both in soluble form in plasma and other body fluids and in insoluble form in interstitial connective tissue, frequently in association with basement membranes and cell surfaces (1). Plasma fibronectin has been demonstrated to mediate several functions like cell attachment, cell spreading, intercellular adhesion, non immune opsonisation and wound healing $(1,2)$.

Under acute phase conditions major changes of the concentration, rates of hepatic synthesis and secretion of several plasma proteins are observed $(3,4)$. While the rate of albumin synthesis is decreased, marked elevations occur in the net synthesis of $\alpha_{1}$-acid glycoprotein, major rat acute phase protein and fibrinogen in rat liver (5). Although several plasma proteins are elevated similarly under acute phase conditions in a great variety of species, there are also known speciesspecific acute phase reactants. C-reactive protein is a prominent reactant in humans and rabbits (6), serum amyloid $A$ in humans and mice (7), $\alpha_{1}$-antichymotrypsin in humans (8), $\alpha_{1}$-acid glycoprotein and $\alpha_{2}$ macroglobulin in rats $(9,10)$.

The role of acute phase proteins in inflammation and/ or modulation of immune response is still unclear, but the regulatory mechanisms involved in the altered protein synthesis have been partially elucidated recently $(11-13)$. Hormones (e.g., dexamethasone) and peptides released by non-parenchymal liver cells (e. g. interleukin-1 or hepatocyte stimulating factor) (13) are suspected to be signals for altered protein synthesis in hepatocytes under acute phase conditions.

Recently, fibronectin was shown to be elevated in the plasma of rats and mice with unspecific inflammation $(14,15)$, but the pathobiochemical mechanism of its elevation, in particular the enhanced synthesis of fibronectin in hepatocytes under these conditions, is not known and requires further investigation. In the present study we have determined the concentration and the rate of hepatocellular synthesis of plasma fibronectin under various acute phase conditions. The results support the view that fibronectin behaves as an acute phase reactant in the rat, showing a greatly exaggerated rate of synthesis in hepatocytes under acute phase conditions.

\section{Materials and Methods}

Source of materials

Turpentine was obtained from Merck AG, Darmstadt, FRG; adrenaline (epinephrine bi-tartrate) from Sigma Chem. Co.,
Munich, FRG; triiodothyronine (Thyrotardin Pharm.) and $L$ thyroxine from Henning, Berlin, FRG; dexamethasone from Medice Chemical Pharma, Iserlohn, FRG. Pentobarbital (Nembutal Pharm.) was from Serva, Heidelberg, FRG. Equipment and reagents for immunoelectrophoresis were all from Sebiachem, Fa. Kinkel, Herbstein, FRG, for Ouchterlony gel diffusion from LKB, Munich, FRG. Fluorescein isothiocyanate labeled protein $\mathrm{A}$ for immunodetection and bovine serum albumin was from Sigma Chem. Co, Munich, FRG, and Triton X100 from Serva, Heidelberg, FRG. Nitrocellulose BA 85 for western blotting was from Schleicher and Schüll, Dassel, FRG. Buffers and media used for the isolation and suspension cultures of hepatocytes were from Flow Laboratories, Bonn, FRG. $\left[{ }^{14} \mathrm{C}\right]$ Valine $(10.4 \mathrm{GBq} / \mathrm{mmol} ; 280 \mu \mathrm{Ci} / \mathrm{mmol})$ was from Amersham Buchler, Braunschweig, FRG.

\section{Treatment of rats}

Male Sprague-Dawley rats (Lippische Versuchtstieranstalt, Extertal, FRG) weighing 200-300 g were starved for $24 \mathrm{~h}$ before treatment with turpentine $(0.5 \mathrm{ml}$ subcutaneously) or hormones. Details of the treatment are described in the legends of the appropriate figures and tables.

Collection of blood and measurement of acute phase reaction

Under anaesthesia with pentobarbital $(54 \mathrm{mg} / \mathrm{kg}), 3$ to $5 \mathrm{ml}$ blood were aspirated from the V. cava inf. and anticoagulated in vials containing $6 \mathrm{mg}$ EDTA (Fa. Kabe, Nümbrecht, FRG) or $106 \mu \mathrm{mol} / 1$ sodium-citrate (Fa. Sarstedt, Nümbrecht, FRG).

The acute phase reaction was monitored by functional determination of the fibrinogen concentration (16) using a KC 10 coagulometer ( $\mathrm{Fa}$. Amelung, Lemgo, FRG) and by routine electrophoresis on cellulose acetate strips with an Olympus Hite 200 system (Olympus, Hamburg, FRG).

\section{Determination of plasma fibronectin concentration}

Plasma fibronectin was measured by laser nephelometry às described previously (17). Polyclonal anti-human fibronectin antiserum cross-reacting with rat fibronectin (lot. 5054) and human fibronectin standard were obtained from Behring Werke, Marburg, FRG. The analytical criteria of the method have been reported elsewhere (17).

\section{Ouchterlony gel diffusion}

Double diffusion (Ouchterlony) plates were prepared to compare the immunreactivity of human and rat plasma fibronectin with rabbit anti-human fibronectin antiserum (Behring Werke AG, Marburg, FRG; lot. 5054) and goat anti-rat fibronectin antiserum (Calbiochem. La Jolla, USA, lot. 405728). Agarose solution (10 $\mathrm{g} / \mathrm{l}$ in $0.05 \mathrm{~mol} / \mathrm{l}$ phosphate buffered saline $\mathrm{pH} 7.4$ ) $(20 \mathrm{ml})$ was poured on to a $10 \mathrm{~cm} \times 10 \mathrm{~cm}$ glass plate. After cooling, $2.5 \mathrm{~mm}$ wells were cut with a gel punch. Rabbit antiserum to human fibronectin and goat antiserum to rat fibronectin were placed in the central wells. Samples of human fibronectin standard, and rat plasma from untreated, $\mathrm{NaCl}$ injected and acute phase animals, were placed in the peripheral wells. The diffusion was carried out at $4^{\circ} \mathrm{C}$ in a humidified atmosphere for at least 2 days.

\section{Immunoelectrophoresis of rat plasma}

Immunoelectrophoresis was performed with commercially available agarose plates at $150 \mathrm{~V}$ for 45 iminutes at $20^{\circ} \mathrm{C}$ according to established procedures $(18,19)$. After electrophoretic separation, $20 \mu \mathrm{l}$ anti-human fibronectin antiserum were 
allowed to diffuse for $20 \mathrm{~h}$ at room temperature. After washing for $24 \mathrm{~h}$ in saline the plates were dried and stained with Ponceau Red S.

Polyacrylamide-gel-electrophoresis of rat plasma followed by western blotting, immunoprecipitation and immunofluorescence staining of fibronectin with fluoresceine isothiocyanate labeled protein $\mathbf{A}$

Plasma protein $(100 \mu \mathrm{g})$ was subjected to slab gel electrophoresis as described elsewhere (20) with a $4 \%$ separation gel buffered with $0.75 \mathrm{~mol} / 1 \mathrm{Tris} / \mathrm{HCl} \mathrm{pH} 8.8$ and a $3 \%$ stacking gel buffered with $0.156 \mathrm{~mol} / \mathrm{l} \mathrm{Tris} / \mathrm{HCl} \mathrm{pH} 6.8$ at $200 \mathrm{~V}$ for $18 \mathrm{~h}$. The electrode buffer was composed of $0.2 \mathrm{~mol} / 1$ glycine and $0.025 \mathrm{~mol} / 1$ Tris pH 8.4. A Multiphor electrophoresis system from LKB Instruments, Munich, FRG was used.

Protein blotting on nitrocellulose was performed at $200 \mathrm{~mA}$ for $3 \mathrm{~h}$ at room temperature (blotting buffer: $0.150 \mathrm{~mol} / \mathrm{l} \mathrm{gly}$ cine, $0.020 \mathrm{~mol} / \mathrm{l}$ Tris, $\mathrm{pH} 8.3,200 \mathrm{ml} / 1$ methanol as described elsewhere (21), incorporating only slight modifications (22). The nitrocellulose sheets were incubated overnight at room temperature with phosphate-buffered saline, $\mathrm{pH} 7.2$ containing $30 \mathrm{~g} / 1$ bovine serum albumin, then washed three times with phosphate-buffered saline containing $1 \%$ triton $X-100$ for 15 minutes. After washing, the antihuman fibronectin antiserum (1: 50 diluted with phosphate buffered saline) was allowed to react overnight, after which the nitrocellulose sheets were washed again 3 times with phosphate buffered saline containing $1 \%$ triton X-100. Immunodetection was performed by incubation with fluorescein isothiocyanate labeled protein $A(2 \mathrm{mg} / \mathrm{l}$ in phosphate buffered saline) for $2 \mathrm{~h}$. For visualization of the fluorescence the nitrocellulose sheet was irradiated with light of $250 \mathrm{~nm}$ (22).

\section{Gelatine 4 B-sepharose gel chromatography}

Columns $(1.6 \mathrm{ml}, 2.5 \mathrm{~cm} \times 0.9 \mathrm{~cm})$ of gelatine $4 \mathrm{~B}$ sepharose (Pharmacia) were equilibrated with $0.05 \mathrm{~mol} / \mathrm{l}$ Tris/ $\mathrm{HCl}$ buffer pH $7.4(23,24)$. Citrated plasma $(0.5 \mathrm{ml})$ was passed through the columns, which were then washed with $5 \mathrm{ml}$ of equilibration buffer. Fibronectin in plasma and wash solution was monitored by laser nephelometry as described above (17).

\section{Isolation and incubation of hepatocytes}

The preparation of rat hepatocytes was performed according to Seglen (25) as previoúsily described (26) and yielded about $40 \times 10^{7}$ hepatocytes per liver contaminated with 1 to $4 \%$ nonparenchymal cells. The viability of the cells was checked with the trypan blue exclusion test and ranged from 70 to $90 \%$. In the suspension cultures the cell density was adjusted to 0.5 to $1.0 \times 10^{7} /$ inl.

Determination of total protein synthesis by incorporation of $\left[{ }^{14} \mathrm{C}\right]$ valine

Hepatocyte suspension $(3 \mathrm{ml})$ was incubated at $37^{\circ} \mathrm{C}$ for $2 \mathrm{~h}$ with $0.22 \mathrm{MBq}(6 \mu \mathrm{Ci})$ of $\left[{ }^{14} \mathrm{C}\right]$ valine in Dulbecco's modification of Eagle's medium under an atmosphere of $0.95 \mathrm{O}_{2}$ and 0.05 $\mathrm{CO}_{2}$ as described previously $(26,27)$. At intervals of 15 or 30 minutes, aliquots of the suspension culture were removed and centrifuged at $500 \mathrm{~g}$ at $4{ }^{\circ} \mathrm{C}$. Supernatant $(100 \mu \mathrm{l})$ was useed for measurement of total protein synthesis according to Mans \& Novelli (28).

Determination of fibronectin synthesis by immunoprecipitation

Culture supernatant $(500 \mu l)$ from $\left[{ }^{14} \mathrm{C}\right]$ valine-exposed hepatocyte suspensions incubated as described above was mixed with
$400 \mu l$ antihuman-fibronectin antiserum cross-reacting with rat fibronectin and $50 \mu \mathrm{l}$ standard human plasma containing $30 \mu \mathrm{g}$ human fibronectin. The mixture was incubated for $48 \mathrm{~h}$ at $4^{\circ} \mathrm{C}$ and thereafter centrifuged at $10000 \mathrm{~g}$. The supernatant was discarded and the pellet was washed 3 times with ice cold phosphate-buffered saline $(1 \mathrm{ml})$. After the final washing the pellet was dissolved in $400 \mu \mathrm{l}$ of $4 \mathrm{~mol} / 1 \mathrm{NaOH}$, mixed with $10 \mathrm{ml}$ Optifluor and counted for radioactivity in a Packard Tricarb 4430 (Packard Instruments, Frankfurt, FRG).

\section{Results}

Characterization of the cross-reactivity of anti-human fibronectin antiserum with rat plasma fibronectin

Cross-reactivity of the anti-human fibronectin antiserum, used here for rat plasma fibronectin, was shown by Ouchterlony gel diffusion (fig. 1). Both the antigen from human and rat plasma forms intense precipitation lines with anti-human fibronectin antiserum, whereas only a very weak immunoprecipitation with human plasma was obtained with an antiserum raised against authentic rat plasma fibronectin (fig. 1). Some differences in the immunoreactivity of fibronectin derived from both species are reflected by the spurs of the precipitation lines. Because the antirat fibronectin antiserum was not suitable for laser

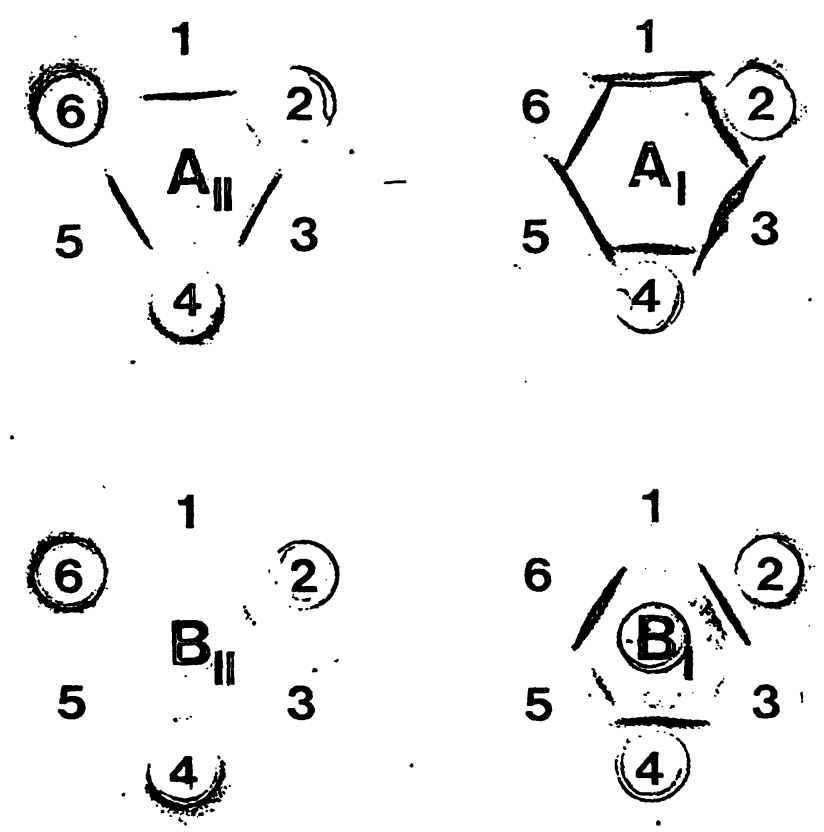

Fig. 1. Ouchterlony gel diffusion assay of human fibronectin standard (wells $1,3,5$ ) and rat plasma of untreated (well 2), saline-injected (well 4) and turpentine-treated (well 6) animals.

The treatment of the animals was similar to that described in fig. 3. Anti-human fibronectin (A) and antirat fibronectin (B) antiserum werc positioned in the central wells (I undiluted; II diluted 1:5). 
nephelometric determination of fibronectin, the cross-reacting anti-human fibronectin antibody was applied in all experiments. After removal of fibronectin from plasma with gelatine, no immunoreactive material was found by gel diffusion assays or nephelometry, which indicates the monospecificity of antihuman fibronectin antiserum for rat fibronectin (tab. 1).

Tab. 1. Determination of the concentration of fibronectin in human and rat plasma, before and after binding of fibronectin to gelatine-sepharose. The assay was performed with anti-human fibronectin antiserum as described in methods. Plasma was obtained from untreated rats, from animals $24 \mathrm{~h}$ after turpentine injection and from rats $24 \mathrm{~h}$ after bilateral deep back incision. The mean values of duplicate measurements are listed.

\begin{tabular}{lll}
\hline Treatment of the rat & \multicolumn{2}{l}{ Fibronectin concentrations (mg/l) } \\
\cline { 2 - 3 } & $\begin{array}{lll}\text { before } \\
\text { gelatine binding }\end{array}$ & $\begin{array}{l}\text { after } \\
\text { gelatine binding }\end{array}$ \\
\hline Starved/untreated & 130 & $<1$ \\
Turpentine & 370 & $<1$ \\
Deep back incision & 410 & $<1$ \\
\hline Human plasma & 280 & $<1$ \\
\hline
\end{tabular}

Plasma fibronectin concentrations under inflammatory, traumatic and hormonal conditions

Twenty four hours after the injection of turpentine, the concentration of the acute phase reactant fibrinogen was elevated (tab. 2) and there was a severe dysproteinaemia (not shown).

Tab. 2. The concentrations of fibrinogen and fibronectin in plasma $24 \mathrm{~h}$ after subcutaneous injection of $0.5 \mathrm{ml}$ saline $(0.154 \mathrm{~mol} /)$ and $0.5 \mathrm{ml}$ turpentine, and in plasma of $24 \mathrm{~h}$ starved but otherwise untreated rats. The plasma fibronectin concentration in rats exposed for $48 \mathrm{~h}$ to a temperature of $4{ }^{\circ} \mathrm{C}$ and subjected to surgical trauma is also given. The mean values $\pm S$. D. are listed, in parenthesis is the number of individual experiments (n. d. = not determined).

\begin{tabular}{lll}
\hline Treatment of the rat & $\begin{array}{l}\text { Fibrinogen } \\
(\mathrm{g} / \mathrm{l})\end{array}$ & $\begin{array}{l}\text { Fibronectin } \\
(\mathrm{mg} / \mathrm{l})\end{array}$ \\
\hline $\begin{array}{l}\text { Starved/untreated } \\
(\mathrm{n}=4)\end{array}$ & $1.5 \pm 0.1$ & $150 \pm 50$ \\
$\begin{array}{l}\mathrm{NaCl} 0.154 \mathrm{~mol} / \mathrm{l} \\
(\mathrm{n}=4)\end{array}$ & $2.0 \pm 0.1$ & $300 \pm 20$ \\
$\begin{array}{l}\text { Turpentine } \\
\text { Cold exposure }\end{array}$ & $\begin{array}{l}5.0 \pm 0.2 \\
(\mathrm{n}=6)\end{array}$ & $\begin{array}{l}412 \pm 59 \\
(\mathrm{n}=23)\end{array}$ \\
$\begin{array}{l}\mathrm{n}=4) \\
\text { Deep back incision } \\
(\mathrm{n}=4)\end{array}$ & $\mathrm{n} . \mathrm{d}$. & $680 \pm 65$ \\
\hline
\end{tabular}

Fibronectin, with a plasma concentration of $150 \mathrm{mg} / \mathrm{l}$ in untreated rats, increased twofold $24 \mathrm{~h}$ after injection of saline, and was even higher at $412+59 \mathrm{mg} / \mathrm{l}$ in turpentine treated rats (tab. 2). The time course of fibronectin elevation under acute phase conditions reveals a rapid increase within $6 \mathrm{~h}$ and a maximum elevation at $24 \mathrm{~h}$ with a gradual decrease thereafter (fig. 2). An elevated plasma fibronectin concentration was also found after exposure of the animals to $4^{\circ} \mathrm{C}$ for $48 \mathrm{~h}$ and after surgical trauma like deep back incision (tab. 2).

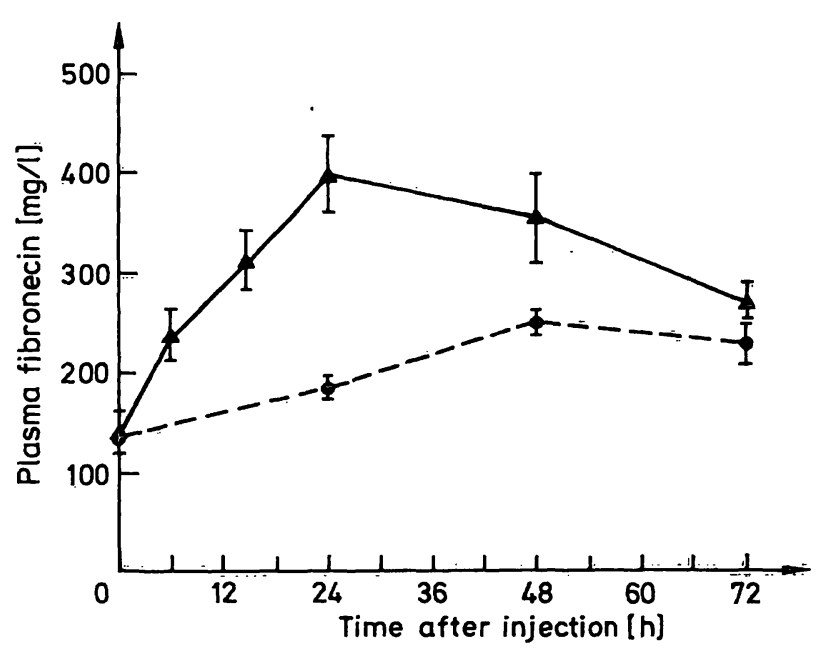

Fig. 2. Plasma fibronectin concentrations in rats at various times after subcutaneous injection of $0.5 \mathrm{ml}$ turpentine $(\Delta-\Delta)$, and in starved, otherwise untreated animals (o-0). All rats were starved $24 \mathrm{~h}$ before starting the treatment and during the whole experimental period. The mean values $\pm S$. D. of $3-4$ experiments are given.

The influences of various hormones on the concentration of plasma fibronectin were studied (tab. 3). Thyroxine, triiodothyronine and adrenaline proved to be without any effect on the concentration of plasma fibronectin, whereas the administration of dexamethasone results after $24 \mathrm{~h}$ in an increase of fibronectin. similar to that observed with turpentine (tab. 3). The combined administration of dexamethasone and turpentine raised the concentration to $660 \mathrm{mg} / \mathrm{l}$ (tab. 3).

Immunological characterization of fibronectin under acute phase conditions

One dimensional immunoelectrophoresis was used to compare plasma protein from normal, turpentine and turpentine + dexamethasone-treated rats with a human plasma fibronectin standard. This enabled us to identify the protein in the plasma of rats under acute phase conditions, which cross-reacts with the antibody against human plasmâ fibronectin (fig. 3). In all samples a single precipitation line with similar 
Tab. 3. The concentration of plasma fibronectin under hormonal treatment compared with values for untreated rats and animals injected with saline $(0.5 \mathrm{ml}$; s. c.). All animals were starved $24 \mathrm{~h}$ before treatment and during the experimental period. The rats were treated with $2 \mathrm{mg} / \mathrm{kg}$ of dexamethasone i. m., $0.2 \mathrm{mg} / \mathrm{kg}$ of adrenaline i. m., $11 \mu \mathrm{mol} / \mathrm{kg}$ of $L$-thyroxine i. p. and $1.93 \mu \mathrm{mol} / \mathrm{kg}$ of triiodothyronine i. p., respectively. An additional group received dexamethasone $(2 \mathrm{mg} / \mathrm{kg})$ and $0.5 \mathrm{ml}$ turpentine s. c. simultaneously. Blood was obtained $24 \mathrm{~h}$ after administration of the hormones. Mean values \pm S. D. and the number of individual experiments (n) are listed.

\begin{tabular}{ll}
\hline Treatment of the rat & $\begin{array}{l}\text { Fibronectin } \\
(\mathrm{mg} / \mathrm{l})\end{array}$ \\
\hline Starved/untreated $(\mathrm{n}=5)$ & $150 \pm 50$ \\
Saline $(\mathrm{n}=5)$ & $300 \pm 20$ \\
Dexamethasone $(\mathrm{n}=11)$ & $425 \pm 98$ \\
Dexamethasone + Turpentine $(\mathrm{n}=7)$ & $660 \pm 49$ \\
Adrenaline $(\mathrm{n}=3)$ & $360 \pm 45$ \\
L-Thyroxine $(\mathrm{n}=3)$ & $320 \pm 47$ \\
Triiodothyronine $(\mathrm{n}=3)$ & $310 \pm 6$ \\
\hline
\end{tabular}

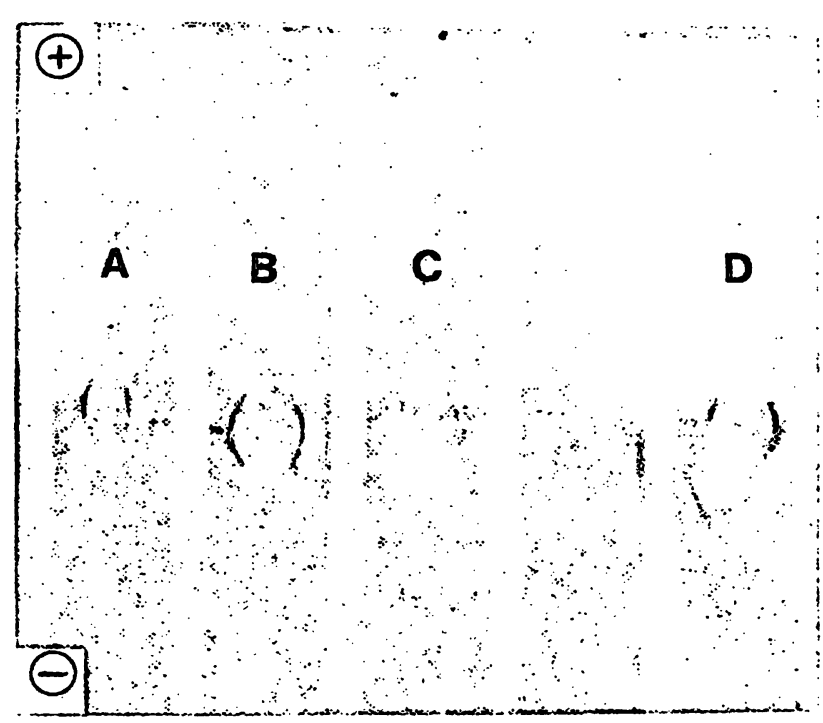

Fig. 3. One dimeñsional immunoelectrophoresis of rat plasma fibronectin. The animals were starved for $24 \mathrm{~h}$ and then treated as follows:

(A) subcutaneous injection of $0.5 \mathrm{ml}$ turpentine and i. $\mathrm{m}$. injection of $2 \mathrm{mg} / \mathrm{kg}$ of dexamethasone simultaneously;

(B) human fibronectin standard;

(C) untreated;

(D) $0.5 \mathrm{ml}$ turpentine. Blood was obtained $24 \mathrm{~h}$ after treatment.

electrophoretic mobility was obtained, which indicates that the immunoreactive protein in rat plasma is fibronectin. This conclusion was supported by slab gel electrophoresis of rat plasma and human fibronectin standard followed by western blotting and immunofluorescence staining with fluoresceine isothiocyanate labeled protein $A$. Single immunoreactive precipitation lines were obtained, and their different intensities reflect the changing concentrations of fibronectin in the plasma of control and acute phase animals (fig. 4).

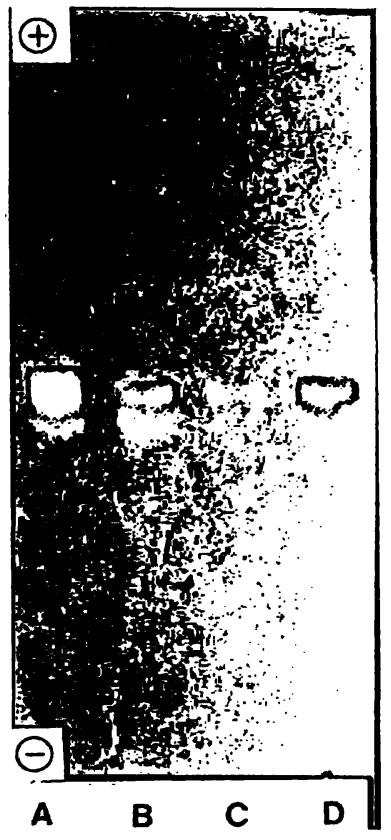

Fig. 4. Gel electrophoresis of rat plasma fibronectin, western blotting and immunofluorescence staining with fluoresceine isothiocyanate labeled protein $\mathrm{A}$.

The treatment of the animals was similar to that described in figure $2.100 \mu \mathrm{g}$ of plasma proteins from

(A) turpentine + dexamethasone,

(B) turpentine treated and

(C) untreated animals were analysed.

Lane (D) represents human plasma fibronectin standard.

Fibronectin synthesis in isolated hepatocytes

Hepatocytes from the livers of control rats and animals injected $24 \mathrm{~h}$ earlier with turpentine were studied in suspension cultures for their capacity to synthesize total protein and fibronectin. After a lag period of 30 minutes the cells started to synthesize total protein at a linear rate, which was about 3 times higher in liver cells from acute phase rats than in control hepatocytes (fig. 5). The synthesis of fibronectin secreted into the culture medium followed a similar time course (fig. 6). Hepatocytes from rats pretreated with turpentine synthesized, during a $2 \mathrm{~h}$ incubation period, about four times as much fibronectin as control hepatocytes (fig. 6). No difference was found between the ratio of fibronectin synthesis versus total protein synthesis in acute phase and control cultures. The fractional synthesis of fibronectin was 0.015 in control and 0.016 in acute phase hepatocytes, after an incubation period of $2 \mathrm{~h}$.

\section{Discussion}

The data reported here demonstrate increased concentrations of fibronectin in rat plasma under acute 


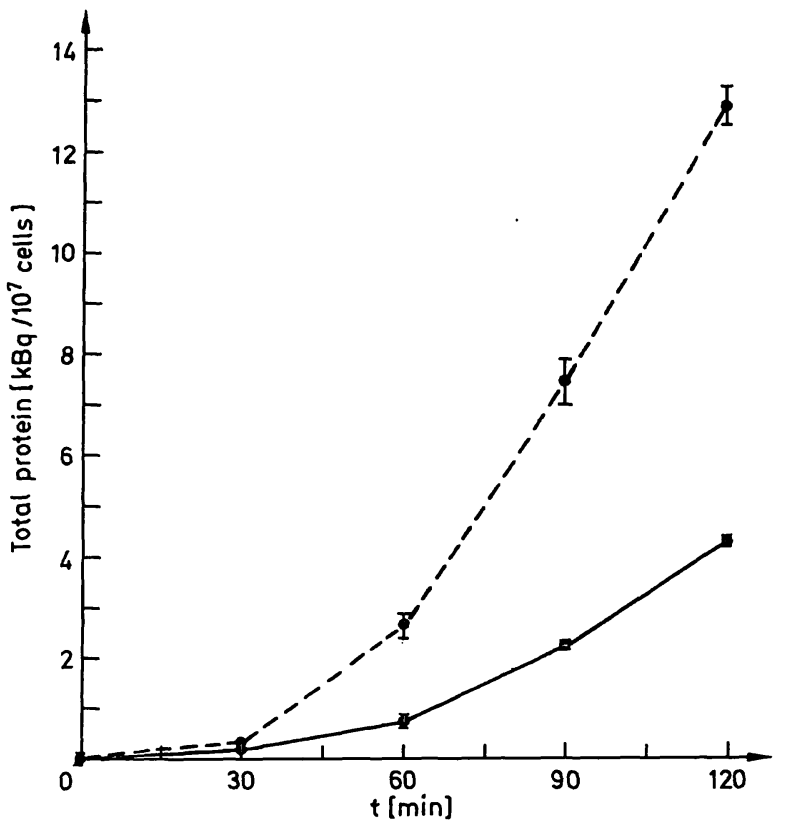

Fig. 5. Time course of total protein synthesis in hepatocyte suspension cultures. Total protein secreted into the culture medium from turpentine-treated $(0---0)$ and saline pretreated $(0-0)$ hepatocytes was measured by incorporation of $\left[{ }^{14} \mathrm{C}\right]$ valine. Treatment of the rats was performed $24 \mathrm{~h}$ prior to the isolation of hepatocytes. The mean values \pm S. D. of 3 experiments are given.

phase conditions. This finding confirms results presented recently, which show elevated plasma fibronectin concentrations in rats with unspecific inflammation (14) and in mice injured by subcutaneous injections of $\mathrm{AgNO}_{3}$ (15). However, the mechanism of elevation and the site of synthesis of plasma fibronectin under these conditions have not been elucidated so far. In order to define clearly a plasma protein as an acute phase reactant it is essential to provide evidence for its stimulated synthesis in hepatocytes under acute phase conditions. Utilizing isolated perfused liver it was shown that the liver in situ might be the main if not the sole site of plasma fibronectin synthesis (14). The most likely cell type responsible for fibronectin production seems to be the hepatocyte, which is able in monolayer cultures to synthesize and to secrete significant amounts of fibronectin (about $3 \%$ of total secreted proteins), which are sufficient to maintain the plasma fibronectin concentration (about $0.4 \%$ of total plasma protein) $(29,30)$. It is noteworthy that the fractional rate of hepatocellular fibronectin synthesis changes with the duration of culture due to phenotypic adaptations of the cell in vitro (31). To circumvent this problem we used short term suspension cultures, which might reflect more accurately the synthesis profile of glycoproteins of hepatocytes in situ. The results obtained contradict some immunofluorescence microscopic studies, which

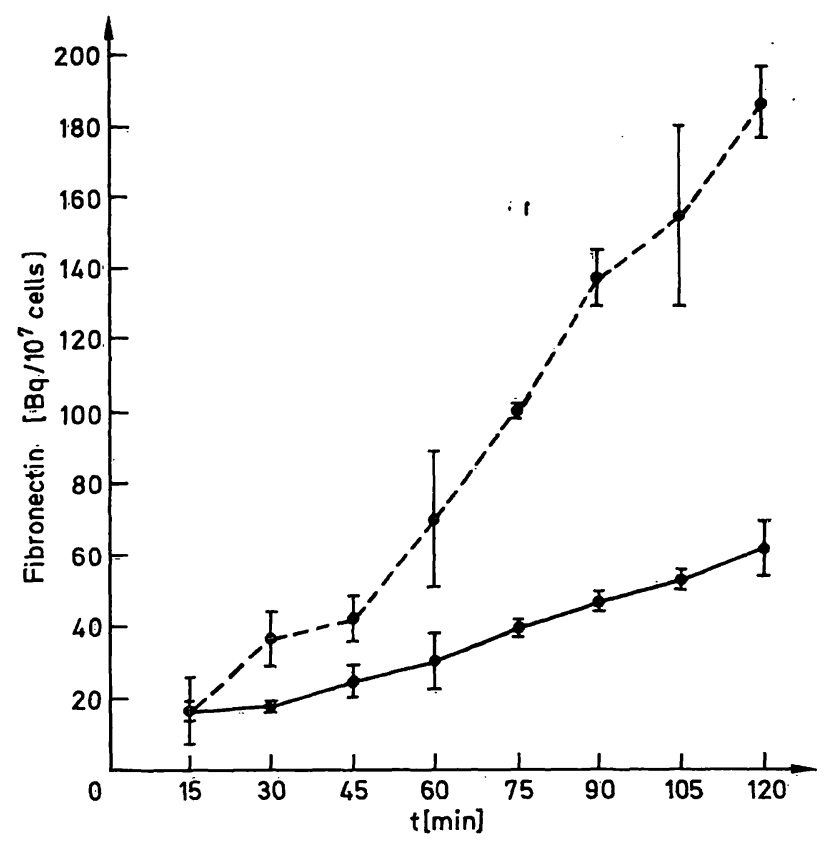

Fig. 6. Time course of fibronectin synthesis in hepatocyte suspension cultures. Fibronectin labeled with $\left[{ }^{14} \mathrm{C}\right]$ valine was immunoprecipitated from the medium of turpentine-treated $(0--0)$ and saline pretrated $(0-0)$ hepatocytes. The mean values $\pm \mathrm{S}$. D. of 3 experiments are given.

failed to detect fibronectin in normal parenchymal liver cells $(32,33)$, but they support other morphological investigations, which immunolocalized fibronectin in normal hepatocytes (34) and in hepatocytes from injured liver "(35). The contribution of endothelial cells (36) and macrophages like Kupffer cells $(37-40)$ to the pool of plasma fibronectin is low, although both cell types are capable of synthesizing this specialized glycoprotein. The demonstration of stimulated fibronectin synthesis in hepatocytes under acute phase conditions supports strongly the important role of the parenchymal liver cells in maintaining the concentration of this glycoprotein in plasma. Due to its short half life of about $25 \mathrm{~h}$ the rate of synthesis in hepatocytes will be the most important determinant of the plasma fibronectin concentration (41).

The mechanism triggering increased synthesis of fibronectin under acute phase conditions is not-known. Our results point to glucocorticoids (dexamethasone) as hormones capable of increasing the concentration of fibronectin in the circulation. Dexamethasone is known to stimulate fibronectin production in the isolated perfused rat liver (14), in avian bepatocytes (30) and rat liver parenchymal cells maintained in monolayer cultures (30). The observation is consistent with the known ability of the hormone to stimulate hepatocyte production of acute phase proteins 
$(11,42-44)$. It remains an intriguing question of future studies to elucidate the role of cytokines like interleukin-1 $(45,46)$ and of the ,hepatocyte stimulating factor" $(13,47-48)$ in the mechanism of stimulated fibronectin synthesis during acute phase response. It is assumed that fibronectin synthesis under these conditions is regulated at the transcriptional level, as shown for a variety of other acute phase reactants (49). The determination of the concentration of the functional mRNA of fibronectin in the liver will answer this question. Our results rule out a significant effect of thyroid hormones on the concentration of fibronectin in rat plasma, although greatly elevated levels have been reported in hyperthyroid patients (50). This discrepancy points to species-specific differences of fibronectin metabolism, which is further supported by the fact that in humans fibronectin has not been recognized so far as an acute phase reactant following major surgery, burns or other trauma (51-53). However, a close ionic interaction of fibronectin with the acute phase reactant C-reactive protein has been established (54). Despite the species-dependent differences in fibronectin metabolism the immunological behaviour characterized by an extensive interspecies cross-reactivity points to fibronectin as a highly conserved molecule during evolution (55). We were thus able to use antihuman fibronectin antiserum to demonstrate that normal, acute phase rat plasma fibronectin, and human fibronectin all behave identically in one dimensional immunoelectrophoresis.

The functional significance of this glycoprotein as an acute phase reactant remains speculative. The multiple biological functions, in particular that of a non-specific opsonin, suggest a role as defense protein in the early phase of inflammation. Increased levels of plasma fibronectin under acute phase conditions might facilitate the removal of microaggregates, bacteria, and soluble debris from the circulation and, thus improve the function of the reticulo-endothelial system $(56,57)$. Furthermore, acute phase fibronectin might be deposited in the tissue at sites of acute inflammation and injury and thereby support wound healing and tissue repair $(58,59)$. Stimulated synthesis of fibronectin in hepatocytes would therefore compensate for its increased consumption under these conditions. On the present evidence, fibronectin, at least in rodents, is an acute phase reactant with important systemic and local functions.

\section{References}

1. Ruoslathi, E., Engvall, E. \& Hayman, E. G. (1981) Coll. Res. 1, 95-128.

2. Hörmann, H. (1982) Klin. Wochenschr. 60, 1265-1277.

3. Kushner, I. (1982) Ann. N.Y. Acad. Sci. 389, 38-48.

4. Koj, A. (1983) In: Pathophysiology of Plasma Protein Metabolism (Mariani, G., ed.) Mac Millan, London, pp. $221-248$.

5. Schreiber, G., Howlett, G., Nagashima, M., Millership, A., Martin, H., Urban, J. \& Kotler, L. (1982) J. Biol. Chem. $257,10271-10277$.

6. Laurent, P. (1982) In: Marker Proteins in Inflammation (Allen, R. C., Bienvenue, J., Laurent, P. \& Suskind, R. M., eds.) Walter de Gruyter \& Co., Berlin, pp. 69-88.

7. McAdam, K. P. W. J., Elin, R. J., Sipe, J. D. \& Wolf, S. M. (1978) J. Clin. Invest. 61, 390-394.

8. Coombes, J., Shakespeare, P. G. \& Babstone, C. F. (1979) Clin. Chim. Acta 95, $201-209$.

9. Urban, J., Chan, D. \& Schreiber, G. (1979) J. Biol. Chem. $254,10565-10568$.

10. Koj, A., Dubin, A., Kasperczyk, M., Bereta, J. \& Gordon, A. H. (1982) Biochem. J. 206, 545-553.

11. Miller, L. L. (1976) In: Protides of the Biological Fluids (Peeters, H., ed.) Pergamon Press, New York, pp. 461 - 469.

12. Jamieson, J. C., Kaplan, A. H., Wolski, B. M. R. N. J., Hellman, M. \& Ham, K. (1983) Can. J. Biochem. Cell. Biol. 61, $1041-1048$.

13. Baumann, H., Jahreis, J. P., Sauder, D. N. \& Koj, A. (1984) J. Biol. Chem. 259, 7331 - 7342.

14. Owens, M. R. \& Cimino, C. D. (1982) Blood 59, $1305-1309$.

15. Dyck, R. F. \& Rogers, S. L. (1985) Clin. Invest. Med. 8, $148-151$.

16. Clauss, A. (1957) Acta Hämatol. 17, 237-246.
17. Gressner, A. M. \& Wallraff, P. (1980) J. Clin. Chem. Clin. Biochem. 18, 797-805.

18. Grabar, P. \& Burtin, P. (1964) In: Immunoelectrophoretic Analysis, Elsevier Publishing \& Co., Amsterdam.

19. Nowotny, A. (1969) In: Basic Exercises in Immunochemistry, Springer-Verlag, New York, pp. 153-155.

20. Cooper, T. G. (1981) In: Biochemische Arbeitsmethoden (Neumeier, R. \& Maurer, H. R., translat.) Walter de Gruyter, Berlin-New York, pp. 179-220.

21. Jarausch, J. \& Kadenbach, B. (1982) Hoppe Seyler's Z. Physiol. Chem. 363, 1133-1140.

22. Kuhn-Nentwig, L. \& Kadenbach, B. (1985) Eur. J. Biochem. 149, 147-159.

23. Vuento, M. \& Vaheri, A. (1979) Biochem. J. 183, $331-337$.

24. Morgenthaler, J.-J., Baillod, P. \& Friedli, H. (1984) Vox Sang. 47, 41-46.

25. Seglen, P. O. (1976) In: Methods in Cell Biology, Vol. XIII, Academic Press, New York, pp. 29-83.

26. Gressner, A. M: \& Grouls, P. (1982) Digestion 23, $259-264$.

27. Gressner, A. M. \& Vasel, A. (1985) Proc. Soc. Exp. Biol. Med. 180, 334-339.

28. Mans, R. Y. \& Novelli, G. P. (1968) Arch. Biochem. Biophys. $94,48-53$.

29. Tamkun, J. W. \& Hynes, R. O. (1983) J. Biol. Chem. 258, $4641-4647$.

30. Amrani, D. L., Falk, M. J. \& Mosesson, M. W. (1985) Exp. Cell Res. 160, 171-183.

31. Voss, B., Allam, S., Rauterberg, J. Ullrich, K., Gieselmann, V. \& v. Figura, K. (1979) Biochem. Biophys. Res. Comm. $90,1348-1354$.

32. Martinez-Hernandez, A. (1984) Lab. Invest. 51, 57-74. 
33. Kojima, N., Isemura, M., Yosizawa, Z., Ono, T., Shimada, Sh., Soga, K., Aoyagi, Y. \& Ichida, F. (1981) Tohoku J. Exp. Med. 135, 403-412.

34. Clement, B., Emonard, H., Rissel, M., Druguet, M., Grimaud, J.-A., Herbage, D., Bourel, M. \& Guillonzo, A. (1984) Cellular \& Molecular Biology 30, 489-496.

35. Martinez-Hernandez, A. (1985) Lab. Invest. 53, 166-186.

36. Birdwell, C. R., Brasier, A. R. K. \& Taylor, A. L. (1980) Proc. Natl. Acad. Sci USA 75, 3273-3277.

37. Rieder, H., Birmelin, M. \& Decker, K. (1982) In: Sinusoidal Liver Cells (Knock, D. L. \& Wisse, E., eds.) Elsevier Biomedical Press, New York, pp. 193-200.

38. Alitalo, K., Hovi, T. \& Vaheri, A. (1980) J. Exp. Med. 151, $602-613$.

39. Villinger, B., Kelley, D. G., Engelmann, W., Kuhn, C. \& McDonald, J. A. (1981) J. Cell. Biol. 90, 711-720.

40. Van De Water, L., Schroeder, S., Crenshaw, E. B. \& Hynes, R. O. (1981) J. Cell. Biol. 90, 32-39.

41. Pussell, B. A., Peake, Ph. W., Brown, M. A. \& Charleswoth, J. A. (1985) J. Clin. Invest. 76, 143-148.

42. Thompson, W. L., Abeles, F. B., Beall, F. A., Dintermann, R. E. \& Wannemacher, R. W. Jr. (1976) Biochem. J. 156, $25-32$.

43. Grieniger, G. \& Granick, S. (1975) Proc. Natl. Acad. Sci USA 72, 5007-5011.

44. Koj, A., Gauldie, J., Regoeczi, E., Sauder, D N. \& Sweeney, G. D. (1984) Biochem. J. 224, 505-514.

45. Bauer, J., Weber, W., Tran-Thi, T. A., Northoff, G.-H., Decker, K., Gerok, W. \& Heinrich, P. C. (1985) FEBS Lett. $190,271-274$.
46. Ramadori, G., Sipe, J. D., Dinarello, C. A., Mizel, S. B. \& Colten, H. R. (1985) J. Exp. Med. 162, 930-942.

47. Ritchie, D. G. \& Fuller, G. M. (1983) Ann. N. Y. Acad. Sci. USA 408, 490-502.

48. Fuller, G. M., Otto, J. M., Woloski, B. M., McGary, C. T. \& Adams, M. A. (1985) J. Cell Biol. 101, 1481-1486.

49. Northemann, W., Andus, T., Gross, V., Nagashima, M., Schreiber, G. \& Heinrich, P. C. (1983) FEBS Lett. 161, 319-322.

50. Alexander, C. M., Lum, S. M. C., Boarman, C., Nicoloff, J. T. \& Kumar, D. (1984) Metabolism 33, 608-611.

51. Högström, H., Borgström, A. \& Haglund, U. (1985) Scand. J. Clin. Invest. 45, 87-89.

52. Saba, T. M. (1982) Clin. Surg. 1, 346-365.

53. Scovill, W. A., Saba, T. M., Kaplan, J. E., Bernard, H. R. \& Pow̄ers, S. R. jr. (1977) Surg. Res. 22, 709-716.

54. Salonen, E.-M., Vartio, T., Hedman, K. \& Vaheri, A. (1984) J. Biol. Chem. 259, 1496-1501.

55. Kuuisela, P., Ruoslathi, E., Engvall, E. \& Vaheri, A. (1976) Immunochemistry 13, 639-642.

56. Saba, T. M. \& Jaffe, E. (1980) Am. J. Med. 68, 577-594.

57. Lanser, M. E. \& Saba, T. M. (1982) Adv. Shock Res. 8, $111-117$

58. Repesh, L. A., Fitzgerald, T. J. \& Furcht, L. T. (1982) J. Histochem. Cytochem. 30, 351-358.

59. Clark, R. A., Quinn, J. H., Winn, H. J., Lanigan, J. M., Dellepella, P. \& Colvin, R. B. (1982) J. Exp. Med. 156, 646-651.

Prof. Dr. A. M. Gressner Dept. of Clinical Chemistry and Central Laboratory Philipps-University Marburg Baldingerstraße D-3550 Marburg 